Journal of Health Promotion and Behavior (2016), 1(1): 42-46

https://doi.org/10.26911/thejhpb.2016.01.01.06

\title{
Factors Associated with Exercise among Elderly in Boyolali, Indonesia
}

\author{
Aniek Puspitosari'1), RB Soemanto²), Mahendra Wijaya ${ }^{2)}$ \\ 1) Health Polytechnic, Poltekkes of Surakarta, Indonesia \\ 2) Department of Social and Political Sciences Faculty, Universitas Sebelas Maret
}

\begin{abstract}
Background: The elderly will face more problems by getting older. One of which is degenerative disease due to of aging process, such as cardiovascular disease. In the year 2001 (SKRT) data indicated that there were $26.4 \%$ elderly suffered from hypertension disease. Exercise for elderly is one of primary preventive actions. Research should be done related to the practice exercise for elderly. This study was aimed to determine the factors of physical exercise for elderly based on health belief model (HBM).

Subjects and Method: This was an analytic qualitative study with cross-sectional design. This conducted in Sobokerto, Ngemplak, Boyolali, Central Java, Indonesia. A total sample of 80 elderly with hypertension and participate in physical exercises. Data analysis used chi square and logistic regression.

Results: The results showed that the perceived susceptibility, perceived benefits, perceived barriers and cues to action have relationship with physical exercise. There is positive relationship and statically significant between perceived susceptibility with high phycical exercise (OR=27.01; $95 \% \mathrm{CI}=2.04$ to $357.91 ; \mathrm{p}=0.012)$, high perceived benefits $(\mathrm{OR}=26.95 ; 95 \% \mathrm{CI}=2.20$ to 392.05 ; $\mathrm{p}=0.010)$, high perceived barriers $(\mathrm{OR}=0.021 ; 95 \% \mathrm{CI}=0.00$ to $0.90 \mathrm{p}=0.044)$, cues to action $(\mathrm{OR}=21.37 ; 95 \% \mathrm{CI}=1.94$ to $259.92 ; \mathrm{p}=0.044)$.
\end{abstract}

Conclusion: The HBM constructs on the physical exercise of elderly who are at risk for hypertension. The most important HBM predictors of physical exercise were perceived susceptibility.

Keywords: physical exercise, elderly, hypertension, health belief model

Correspondence:

Aniek Puspitosari. Health Polytechnic, Poltekkes of Surakarta Indonesia.

\section{BACKGROUND}

Based on data from the Central Bureau of Statistics or Badan Pusat Statistik (BPS) in 2012, a total of 18 million populations with life expectancy Usia Harap Hidup (UHH) 60 years and over and in 2020 was estimated at 29 million. World Bank described the research institute in UHH stood at 71 years old in 2012 and could be at level of 81 years in 2050.The elderly is population at risk of getting health problems (Stanhpoe and Lancaster, 2000).

The elderly population is a population at risk of getting health problems (Stanhope and Lancaster, 2000). Elderly least has a chronic disease that can be con- sidered as vulnerable populations. Vulnerable groups (vulnerable population) are a group or part of the population is susceptible or vulnerable as a result of exposure to risk or harmful effects on the health of the overall population (Stanhope and Lancaster, 2000; Leight, 2003). Hitchcock et al., (1999) suggests a chronic disease that usually affects the elderly one of which is hypertension also increased the vulnerability and exacerbated by poverty, lack of resources and inadequate services for the elderly. The prevalence of hypertension in the elderly is very high, ie $60 \%-80 \%$ at the age above 65 years. Hypertension can lead 
to various complications include heart failure and stroke (Muhammad, 2010).

The Ministry of Health improve the health status of the elderly does some programs, one through integrated health post or Posyandu program. Government program in 2004 improved health with the occurrence of physical training or exercise. Regular physical exercise is essential to maintaining the physical condition of the elderly, lower the risk of falls and into the street to live independently (WHO, 2011). Physical exercise is recommended gymnastic elderly (Sumintarsih, 2006).

Based on interview with the chairman of cadre Posyandu, the number of the elderly on April 2014 with 629 elderly and 150 elderly were actively participated in exercises for elderly in Posyandu. It means 23\% of the elderly more productive in district Ngemplak, Boyolali. The data indicate that there is still less elderly who participated in physical exercises.

The diversity of factors involved lack elderly doing exercise, we need a study to determine what factors are influential to increase participation elderly doing gymnastic activities. Development of the concept of participation or adherence behaviors related to the interaction with one's health trust is the Health Belief Model (HBM). Rosenstock (1966) explains that HBM can be used to predict the behavior of health improvement that is based on the behavior of individuals is determined by the motives and beliefs of individuals. HBM concept explains that an individual's behavior depends on the value of, a particular outcome or the perceived benefits and the estimated results obtained from the action taken (Erackel et al., 1984 in Stanley and Beare, 1999).

\section{SUBJECTS AND METHOD}

This was an observational analytic study with cross sectional design. This was conducted in Sobokerto, Ngemplak, Boyolali, Indonesia. A total of 80 samples were aged 45 years and over who suffer from hypertension. The sampling technique used random cluster sampling.

The independent variables are the perception of the seriousness, the threat of disease, perceptions of barriers, perceived benefits, and user behavior to act. The dependent variable in this study is the physical exercises for elderly.

Data collection was using primary data obtained directly from the elderly with hypertension who were doing physical exercises. The instrument used a questionnaire that was tested with Pearson product moment validity and reliability Cronbach Alpha.

\section{RESULTS}

The analysis bivariate using Chi Square obtained the following results: there is a relationship between the perceived threat of the seriousness of the threat of disease to practice gymnastics elderly and statistically significant $(\mathrm{p}<0.001)$, there is a relationship perceptions of benefits to the practice gymnastics elderly and statistically signifycant ( $\mathrm{p}<0.001)$, there is a relationship perception barriers to practice gymnastics elderly and statistically significant ( $\mathrm{p}<0.001$ ), there is a relationship behaviors instructions to act with practice gymnastics elderly and statistically significant ( $\mathrm{p}<0.001$ ).

Multivariate analysis using multiple logistic regressions is used to determine the seriousness of the relationship of perception, the perception of the benefits and perceived barriers, behavioral instructions to act with elderly gymnastics. 
Journal of Health Promotion and Behavior (2016), 1(1): 42-46

https://doi.org/10.26911/thejhpb.2016.01.01.06

Table 1. Analysis Logistic Multivariate Regression

\begin{tabular}{lcccc}
\hline \multirow{2}{*}{ Variables } & \multirow{2}{*}{ OR } & \multicolumn{2}{c}{$\mathbf{9 5 \%}$ CI } & \multirow{2}{*}{$\mathbf{p}$} \\
\cline { 3 - 4 } & & Lower limit & Upper limit & 0.012 \\
Perceived Seriousness & 27.01 & 2.04 & 357.91 & 0.010 \\
Perceived Benefits & 26.95 & 2.20 & 329.95 & 0.044 \\
Perceived Barriers & 0.021 & 0.00 & 0.90 & 0.012 \\
User Behavior & 21.37 & 1.94 & 235.92 & \\
N Observational=80 & & & & \\
-2 log likelihood= 24.979 & & & & \\
Nagelkerke R $\mathrm{R}^{2}=83.7 \%$ & & & & \\
\hline
\end{tabular}

Table 1 can be explained as follows, Odd Ratio value variable at 27.01 perception of seriousness of the disease means that elderly people with high perception of the seriousness of the threat of disease has 27.01 times greater possibility of doing gymnastics elderly compared with the perceived threat of the seriousness of the disease is low. Wald test results showed no association with the perception of the seriousness of the threat of disease and the elderly gymnastics statistically significant.

Odd Ratio value perception variable benefits amounted to 26.95 means that elderly people with high perception of the benefits of having the possibility of 26.95 times more likely to do gymnastics elderly than in the elderly with low benefit perception. Wald test results showed no association with exercise benefits elderly perception and statistically significant.

Odd Ratio variable value perception barriers of 0.021 means that elderly people with high barriers of perception are possibly 0,021 times more likely to not do gymnastics elderly than the elderly with low barriers of perception. Wald test results showed no association with gymnastics elderly perception barriers and statistically significant.

Odd Ratio Value User behavior variables act of 21.37 means that elderly people with behavioral instructions act both have 21.37 times greater possibility of doing gymnastics elderly elderly compared with behavioral instructions to act is lacking. Wald test results showed no association with gymnastic act behavioral instructions elderly and statistically significant.

Negelkerke value $\mathrm{R}^{2}$ of $83.7 \%$ means that four independent variables (perceived seriousness of the threat of disease, perceived benefits, perceived barriers, and user behavior act) able to explain the implementation of the elderly gymnastics practice of $83.7 \%$ and the remaining $16.3 \%$ is explained by other factors outside the research model.

\section{DISCUSSION}

The results showed that the higher the respondent's perception about the seriousness or severity of hypertension or hypertension respondents is prone to statistically guarantee of doing gymnastics elderly. They sought to avoid being struck by the severity or complications of the disease. The results of this study are supported by research Iranagh \& Montelbi (2015) that the perception of vulnerability has the highest influence on the behavior of 200 elderly women in physical activity. The more people have a perception of severity of hypertension is high then the more it will take action to prevent hypertension in order to avoid a more severe illness or complications. The results of Kamran et al., (2014), found that $80.7 \%$ of respondents stated that hypertension is a very serious disease and take action to stop smoking and exercise. While those whose 
seriousness lower not take action to stop smoking and exercise.

Respondents with high benefit perception which means the benefit of an action to prevent the disease, it will prefer to perform these actions on a regular basis. Results Iskandar (2012), showed that exercisers elderly have an influence on changes in blood pressure of hypertensive patients. With the benefits of exercise makes the elderly more elderly maintain her health by doing gymnastics elderly.

Increasingly feeling the magnitude of the barriers to the success to behave behavior is getting smaller. The results of this study are supported by Pertiwi (2013), which states that the distance to health care is an important factor in the use of health services. Suhadi (2011) described the factors that most affect adherence in the treatment of hypertension is the cost of treatment. Society tends to take advantage of existing facilities around their homes at a low cost.

The stronger the user behavior act of family, environment and health workers to the elderly hypertension through material support, information and emotion, the more increase the participation of the elderly gymnastics. Rachma (2010) resulted that the family support and the support of health workers affect the implementation of the elderly gymnastics practice.

This study concludes that the most dominant variable in implementing elderly gymnastics practice is variable threat perception seriousness of the disease, which means the use of theoretical Health Belief Model appropriate to describe implementation of the elderly gymnastics practice.

\section{REFERENCE}

Agustina E (2010). Factors associated with elderly gymnastics practice in social institutions Tresna Veda (PSTW) Budi
Mulia 01 Cipayung in East Jakarta. Thesis. Jakarta: UIN.

Hitchcock JE, Schubert PE, Thomas SA (1999). Community Health Nursing: Caring in Action. Albani: Delmas Publisher.

Hoseini H, Maleki F, Moeini M, SharifiradG (2014). Investigating the effect of an education plan based on the health belief model on the physical activity of women who are at risk for hypertension. Iranian Journal of Nursing and Midwifery Research 19(6): 647652.

Iranagh J, Motallebi S (2016). The effect of health belief model based on education intervention on physical activity of elderly women. Journal of Nursing and Midwifery Urnia University of Medical Sciences. 13(12): 1050-1058.

Kamran A, Aharai S, Biria M, Malepour A, Heydari H (2014). Determinants of patient's adherence to hypertension medications: Application of health belief model among rural patients. Ann Med Health Sci Res4(6): 922927.

Kasser S, Kosma M. (2012). Health Beliefs and Physical Activity Behavior in Adults with Multiple Scleroris. Disability and Health Journal5(4): 261268.

Leight SB (2003). The application of a conceptual model to vulnerable populations rural health. Public Health Nursing 20(6): 440-448.

Margiyati (2010). Elderly Gymnastics influence on Blood Pressure Decline in the Elderly Patients with Hypertension in the Elderly IHC Ngud Sane Kemloko Dusun Desa Bergas Kidul, Semarang. Ejournal Undip.

Murti B(2013). Design and Sample Size for Quantitative and Qualitative Research 
Journal of Health Promotion and Behavior (2016), 1(1): 42-46

https://doi.org/10.26911/thejhpb.2016.01.01.06

in Health. Yogyakarta: Gadjah Mada University Press

Pertiwi HW (2013). Factors associated with presence frequency in posyandu elderly seniors. Scientific Journal of Obstetric 4.

Rachma N (2010). Experience phenomenology study seniors doing treatment of high blood pressure in the village Ngresep Banyumanik District of Semarang, Central Java. Thesis. Jakarta: FK UI.

Sas-Nowosielski K, Grabara M, Andrzej H (2013). Health belief model variables as predictors of light, moderate and vigorous physical activity among young adults. New Educational Review. 32(2): 194.

Stanhope M, Lancaster J (2004). Commuity and Public Health Nursing, 6th ed. USA: Mosby.
Strecher, Rosenstock (1997). The Health Belief Model. In Glanz, Lewis \& Rimer (Eds.). Health behavior and health education: Theory and practice research. San Francisco: Josey -Bass

Suhadi (2011). Analysis of factors affecting compliance hypertension treatment in elderly in Srondol regional health center, Semarang. Thesis. Jakarta: Indonesia University.

Sumintarsih (2006). Physical Fitness for Seniors. Sports magazine, ed August, 147-150.

World Health Organization (2011). Global Recommendations on Physical Activity for Health 65 Years and Above. Retrieved December 14, 2014, http://www.who.int/ dietphysicalactivity / pa / en / index.html. 